\section{Highly Successful Adventitious Root Formation of Zamia L. Stem Cuttings Exhibits Minimal Response to Indole-3- Butyric Acid}

\author{
Benjamin E. Deloso \\ Western Pacific Tropical Research Center, University of Guam, UOG \\ Station, Mangilao, Guam 96923
}

Anders J. Lindström

Nong Nooch Tropical Botanic Garden and Resort, Chonburi, Thailand 20260

\author{
Frank A. Camacho and Thomas E. Marler \\ College of Natural and Applied Sciences, University of Guam, UOG Station, \\ Mangilao, Guam 96923
}

Additional index words. asexual propagation, cycad, IBA, Zamia furfuracea, Zamia integrifolia

\begin{abstract}
The influences of indole-3-butyric acid (IBA) concentrations of $0-30 \mathrm{mg} \cdot \mathrm{g}^{-1}$ on the success and speed of adventitious root development of Zamia furfuracea L.f. and Zamia integrifolia L.f. stem cuttings were determined. Root formation success for both species was greater than $95 \%$. The IBA concentrations did not influence the speed of root development for $Z$. furfuracea, but the $Z$. integrifolia cuttings that received IBA concentration of $3 \mathrm{mg} \cdot \mathrm{g}^{-1}$ generated adventitious roots more slowly than the cuttings in the control group. The ending dry weights of the stems, leaves, and roots were not influenced by IBA concentration for either species. Our results indicated that adventitious root formation on stem cuttings of these two Zamia species is successful without horticultural application of IBA. Additional IBA studies are needed on the other 300+ cycad species, especially those that are in a threatened category.
\end{abstract}

The role of horticulture in the conservation programs of rare plant species and habitat restoration has become increasingly important in recent years (Marler, 2017). The skills of horticulturists are uniquely suited for plant conservation work (Kay et al., 2011). Proficient horticultural practices may particularly benefit plant species that are threatened with extinction or nearing extirpation in the wild. Cycads are the most endangered group of plants worldwide, with more than $63 \%$ of described taxa listed under one of the threatened categories (Brummitt et al., 2015; Fragniere et al., 2015). Cycads are a geologically primitive extant group of

Received for publication 3 June 2020. Accepted for publication 29 June 2020.

Published online 31 July 2020.

Financial support was provided by the U.S. Forest Service and the Western Pacific Tropical Research Center, University of Guam.

We thank Frankie Matanane and Charles Paulino for assistance with maintaining the experimental units and for help with preparation of the stem cuttings.

B.E.D. is the corresponding author. E-mail: delosob@ triton.uog.edu.

This is an open access article distributed under the CC BY-NC-ND license (https://creativecommons. org/licenses/by-nc-nd/4.0/).

seed plants whose origins have been traced back to the late Paleozoic era (270-250 mya), reaching their maximum worldwide diversity during the Jurassic era (193-136 mya) (Jones, 1993; Mamay, 1969; Norstog and Nicholls, 1997). Due to their ancient origins and attractive forms, cycads have become more popular in the horticulture trade and are becoming more commercially available.

Sexual and asexual methods of cycad propagation have been used in the horticulture industry. Both methods were reviewed by Dehgan $(1983,1999)$ outlining the advantages and disadvantages of each method. Some cycad species produce adventitious stems especially near the base of the main stem, and these are known as "pups" (Norstog and Nicholls, 1997; Stopes, 1910; Tang, 1985). Adventitious roots (AR) are often induced on these detached pups during successful asexual propagation protocols. Additionally, some cycad species such as Cycas micronesica K.D. Hill that are adapted to frequent tropical cyclones may form natural vegetative propagules after falling, where they subsequently form adventitious roots at the points of soil contact with the stems (Marler and Cruz, 2017b).

The synthetic auxin IBA was among the first plant hormones used for enhancing root formation on plant stems (Cooper, 1935).
Since the introduction of IBA more than 70 years ago, it has been the subject of hundreds of publications. A greater ability of IBA to promote AR compared with indole-3-acetic acid may in part be to its greater stability (Hartmann et al., 1990).

Several propagation studies with cycad species have employed the use of IBA. For example, Z. integrifolia plants that had the zygotic taproot severed and dipped in 2-4 $\mathrm{mg} \cdot \mathrm{g}^{-1}$ IBA usually produced two or more roots to replace the severed section of the taproot (Dehgan, 1983; Dehgan and Johnson, 1987; Dehgan et al., 1994). Large C. micronesica stem cuttings from unhealthy trees exhibited moderate rooting success, and large stem cuttings from healthy trees exhibited $100 \%$ success when the cut end was dipped in a commercial $3 \mathrm{mg} \cdot \mathrm{g}^{-1}$ IBA product (Marler and Cruz, 2017a; Marler, 2018c). Pups of three Cycas species exhibited AR formation of $75 \%$ to $92 \%$ with the use of $3 \mathrm{mg} \cdot \mathrm{g}^{-1}$ IBA (Marler et al., 2020).

These studies on asexual propagation of cycads illuminate the success and relative ease of propagation using commercial IBA products. However, to our knowledge there have been no published IBA dose response studies for any cycad species. Moreover, most of the 356 described cycad species (Calonje et al., 2020) have not been represented in the asexual propagation literature. Our objective was to determine the influence of IBA concentrations of 0 to $30 \mathrm{mg} \cdot \mathrm{g}^{-1}$ on the success and speed of adventitious root formation on Z. furfuracea and Z. integrifolia stem cuttings.

\section{Materials and Methods}

Seedlings aged six years old of the Mexican cycad Z. furfuracea in $210-\mathrm{mL}$ tubes were used to make stem cuttings for a replicated propagation study at the University of Guam. The experiments were repeated with seedlings aged six years old of $Z$. integrifolia, a related species native to the southeastern United States. These model species were chosen based on local availability, abundance in the nursery trade, and relative ease of horticultural care.

Plants without noticeable active leaf expansion were used. All leaves were pruned at the base of each petiole, and the zygotic taproot was cut at the base of each stem to remove all root tissue and expose a clean cut at the base of each stem. This is an unambiguous endeavor because vascular tissue arrangement differs in stem and root tissues and can be easily observed on the open wound (Marler et al., 2010). Water pressure was used to clean the stems, then they were air dried for $30 \mathrm{~min}$. The fresh weight of each stem cutting was recorded.

Each stem cutting was first dipped in $10 \%$ bleach solution (The Clorox Company, Oakland, CA), then in a $0.13 \%$ Daconil fungicide solution (Techpac LLC, Atlanta, GA), then surface water was allowed to air-dry. The Hormex root stimulant powder (Brooker Chemical Corp., Chatsworth, CA) was used 
as our source of IBA. The cut end of each stem was dipped into one of the concentrations: $0,3,8,16$, or $30 \mathrm{mg} \cdot \mathrm{g}^{-1}$. The exposed parenchyma was then covered with a commercial tree sealant and air dried for $24 \mathrm{~h}$.

Clear 2.84-L Cambro containers (Cambro Manufacturing Company, Huntington Beach, CA) were used for the study. One container was designated as a replication that contained one cutting per IBA dose level, with five stem cuttings per replication, for a total of 25 replications. Similarity in stem diameter was used to select the five cuttings for each replication. The containers were prepared with drainage holes drilled $5.5 \mathrm{~cm}$ apart to ensure that each stem cutting was positioned with equal spacing from each other and at a homogeneous distance to drainage holes.

Perlite (Therm-O-Rock West, Inc, Chandler, AZ) was filled to the $2.37 \mathrm{~L}$ level, with $5.5 \mathrm{~cm}$ between the bottom of each stem cutting and the bottom of each container. Each cutting was placed in a diagonal pattern so that each cutting had access to two drainage holes, with a total of twelve drainage holes per replication. The cuttings were assigned to each available position in a random manner. After placing the cuttings directly on the perlite, the containers were then filled with additional perlite to the 2.84-L level and watered, with only the bottom of the stem cuttings submerged in perlite (Fig. 1). The date of planting for each replication was recorded. The start date for the $Z$. furfuracea study was 15 Dec. 2017, and for the $Z$. integrifolia study was 4 July 2018. Containers were placed under $50 \%$ shade, positioned in a Randomized Complete Block design with each container treated as a block, and maintained under plexiglass rain exclusion.

The high and low temperatures were recorded daily throughout the experiment using an AcuRite outdoor thermometer (Chaney Instrument Company, Lake Geneva, WI) covered with a radiation shield. Containers were watered three times weekly. The bottom surface of the experimental pots was inspected daily until adventitious roots made first contact with the bottom surface. This approach enabled the determination of speed of root formation without disturbing the perlite or cuttings.

Each individual rooted cutting was removed from the perlite at the time of root contact with the container's bottom surface, then was planted into 2.6-L containers filled with a medium consisting of $50 \%$ sunshine mix \#4: 25\% \#16 sand: $25 \%$ field soil. This medium had about equal volumes of peat, perlite, sand, and soil. Other nondestructive variables were also recorded throughout the duration of the experiment. These included factors such as the date of first leaf emergence, the date of cutting death (if mortality occurred), and the overall appearance of the AR system at the time of removal from perlite. Photographs were used to aid in this endeavor.

The plants were maintained until the final cutting in each experiment produced AR or was identified as dead. On this date, all plants were bare rooted, then separated into roots, stems, and leaves. The fresh weight of each organ was recorded, and the number of coralloid root clusters was counted for each plant. Each stem was cut in half with a radial section to reveal the precise location that adventitious roots were initiated at the base of each cutting. Each plant organ was placed into a forced draft oven at $75^{\circ} \mathrm{C}$ for $48 \mathrm{~h}$, then the dry weight was recorded.

Statistical analyses were performed using $\mathrm{R}$ commander ( $\mathrm{R}$ package version 2.6-0). Response variables were subjected to an analysis of variance (ANOVA) with IBA dose as the single factor. For each significant response variable, a Tukey's post hoc test was used for means separation.

\section{Results}

The Z. furfuracea study lasted $266 \mathrm{~d}$, from Dec. 2017 to Sept. 2018. The mean high temperature during this study was $36.1 \pm$ $3.1{ }^{\circ} \mathrm{C}$, while the mean low temperature was $26.8 \pm 1.5{ }^{\circ} \mathrm{C}$. The IBA treatments did not influence the days to first root contact, root dry weight, stem dry weight, leaf dry weight, number of coralloid clusters, or initial leaf emergence (Table 1). The percent rooting success (not subjected to ANOVA) was $96 \%$

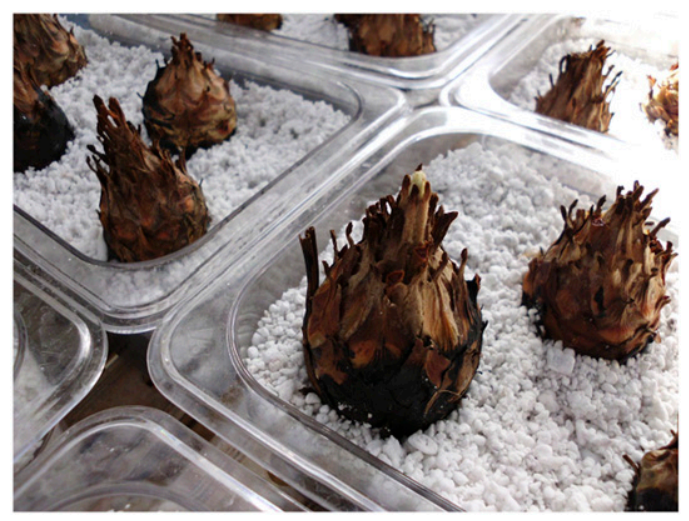

Fig. 1. Zamia furfuracea stem cuttings in perlite in clear 2.84-L Cambro containers.

for the control and $16 \mathrm{mg} \cdot \mathrm{g}^{-1}$ plants, and $100 \%$ for the 3,8 , or $30 \mathrm{mg} \cdot \mathrm{g}^{-1}$ plants.

The Z. integrifolia IBA study lasted $356 \mathrm{~d}$, from July 2018 to June 2019. The mean high temperature during this study was $33.9 \pm$ $2.4^{\circ} \mathrm{C}$, while the mean low temperature was $26.0 \pm 1.2{ }^{\circ} \mathrm{C}$. The days to first root contact differed among the dose levels $(P=0.033)$, and the control group ( $0 \mathrm{mg} \cdot \mathrm{g}^{-1}$ IBA) required an average of $56 \mathrm{~d}$ to root, compared with the $3 \mathrm{mg} \cdot \mathrm{g}^{-1}$ IBA treatment, which required an average of $77 \mathrm{~d}$ (Fig. 2). The 8 , 16 , and $30 \mathrm{mg} \cdot \mathrm{g}^{-1}$ plants did not differ from the 0 or $3 \mathrm{mg} \cdot \mathrm{g}^{-1}$ plants in speed of root formation. The IBA treatments did not influence root dry weight, stem dry weight, leaf dry weight, coralloid root cluster number, or initial leaf emergence (Table 1). The percent rooting success (not subjected to ANOVA) was $100 \%$ for the control and $30 \mathrm{mg} \cdot \mathrm{g}^{-1}$ plants, $96 \%$ for the $3 \mathrm{mg} \cdot \mathrm{g}^{-1}$ plants, and $92 \%$ for the 8 and $16 \mathrm{mg} \cdot \mathrm{g}^{-1}$ plants.

The radial sections of the rooted stem cuttings revealed similar behavior for the two Zamia species (Fig. 3). For the base of every cutting, the adventitious roots were initiated within the radial space occupied by the vascular cylinder. The vascular tissues within the adventitious roots exhibited integrity with the pre-existing vascular tissues in the stem cuttings.

\section{Discussion}

The use of IBA in asexual propagation of plants has become commonplace in the horticulture trade. A significant response to our IBA concentrations was expected based on results from studies on various angiosperm species and the gymnosperm Ginkgo biloba (e.g., Azad and Matin, 2015; Brondani et al., 2012; Ky-Dembele et al., 2011; Purohit et al., 2009; Shirzad et al., 2012). Specific IBA concentrations promoted the most robust $\mathrm{AR}$ systems and aided in more successful propagule establishment in these studies. In contrast to these studies, AR formation in the stem cuttings of these two Zamia species exhibited similar speed (64 d for Z. furfuracea and $67 \mathrm{~d}$ for $Z$. integrifolia) and extremely high success rates $(98 \%$ for $Z$. furfuracea and $96 \%$ for $Z$. integrifolia) regardless of IBA dose. The single response variable that exhibited a significant response was speed of root formation for $Z$. integrifolia. However, the difference between the fastest dose and the slowest dose was only $21 \mathrm{~d}$, and we consider this of minimal horticultural significance. These cuttings required no intermittent mist or other highmaintenance horticultural input, and our maintenance procedures were limited to irrigation three times per week.

Our study is unparalleled for several reasons. First, all past reports on the use of IBA in cycad asexual propagation did not include a control group with no exogenous IBA, so attempts to attribute the documented AR formation to IBA was ambiguous. Second, these past reports did not include more than one IBA dose, so conclusions about optimal 
Table 1 . The response of Zamia furfuracea and Zamia integrifolia stem cuttings to indole-3-butyric acid concentrations of $0,3,8,16$, or 30 mg. ${ }^{-1}$. $\mathrm{N}=25$.

\begin{tabular}{|c|c|c|c|c|c|c|}
\hline Response variable & Minimum & Maximum & Mean & SE & $F$ & $P$ \\
\hline \multicolumn{7}{|c|}{ Zamia furfuracea } \\
\hline Days to first root contact (days) & 36 & 136 & 64 & 1.75 & 1.55 & 0.19 \\
\hline Days to leaf emergence (days) & 25 & 188 & 73 & 1.98 & 0.62 & 0.65 \\
\hline Coralloid root clusters (clusters) & 0 & 25 & 6 & 0.33 & 0.30 & 0.88 \\
\hline Root dry weight $(\mathrm{g})$ & 0.15 & 74.37 & 8.48 & 0.78 & 1.19 & 0.32 \\
\hline Stem dry weight (g) & 10.78 & 64.3 & 26.04 & 0.91 & 0.76 & 0.55 \\
\hline Leaf dry weight (g) & 0 & 43.7 & 11.81 & 0.57 & 0.46 & 0.77 \\
\hline \multicolumn{7}{|c|}{ Zamia integrifolia } \\
\hline Days to first root contact (days) & 40 & 215 & 77 & 2.24 & 2.72 & 0.03 \\
\hline Days to leaf emergence (days) & 24 & 272 & 75 & 1.92 & 2.24 & 0.06 \\
\hline Coralloid root clusters (clusters) & 0 & 32 & 10 & 0.60 & 0.98 & 0.50 \\
\hline Root dry weight (g) & 0.52 & 22.90 & 7.23 & 0.29 & 0.94 & 0.43 \\
\hline Stem dry weight (g) & 3.93 & 28.34 & 12.90 & 0.38 & 0.05 & 0.99 \\
\hline Leaf dry weight (g) & 0.03 & 19.27 & 9.30 & 0.32 & 0.83 & 0.50 \\
\hline
\end{tabular}

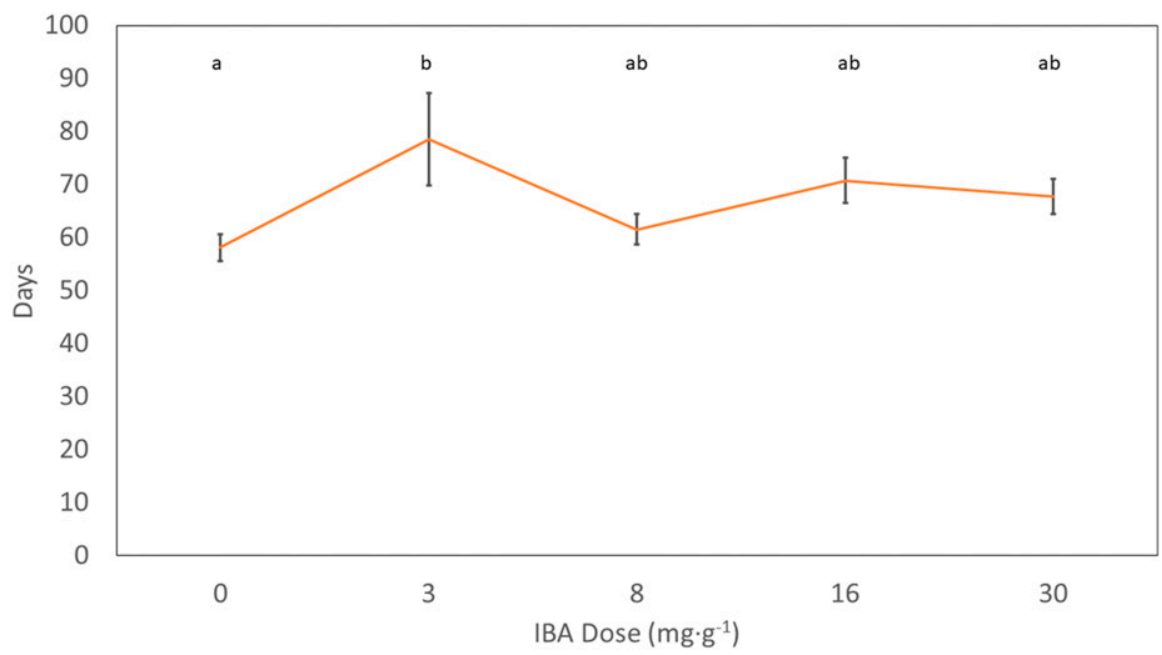

Fig. 2. The influence of indole-3-butyric acid (IBA) concentrations on the number of days required for root contact with the base of the container for Zamia integrifolia stem cuttings. Mean $\pm \mathrm{SE}, \mathrm{N}=25$. Markers with the same letter are not different according to Tukey post hoc test, $P<0.05$.

dosage were not possible. Third, we used an unprecedented number of replications to improve credibility ( 25 per study), while the number of replications was not reported for most of the past reports. Fourth, our use of destructive sampling to obtain dry weights to quantify plant growth has never been used in any prior cycad horticultural study. Fifth, our highest dosage included more active ingredient than any previous cycad study. We note that the commonly available retail products that lay horticulturists can procure from retail markets are limited in concentrations below 3 $\mathrm{mg} \cdot \mathrm{g}^{-1}$. Therefore, we included an IBA dose that was 10 -fold greater than these products. These traits of our methods lend credibility to our results.

Our results suggest that Zamia stem cuttings do not benefit from the use of commercial IBA products. These findings are also likely for stem cuttings from other cycad genera, based on our collective experiences. Our results highlight the relative ease and high survivability when propagating cycad plants asexually if hygienic conditions are adhered to, cuttings are obtained from healthy plants (Marler, 2018c), the cut surfaces are covered with a sealant to prevent desiccation (Marler et al., 2020), the medium exhibits adequate aeration and drainage capacity, and underwatering during the propagation phase is followed (Whitelock, 2002).

Some cycad stem cuttings have been known to "sit" for many months before AR initiation and stem growth resumption (Dehgan, 1999; Marler and Cruz, 2017b). Some of the Zamia cycad stem cuttings used in our studies exhibited this behavior, in that they required up to 11 months to exhibit root or stem growth. The reasons that some cycad cuttings exhibit this behavior despite excellent horticultural care is unknown and requires further research, as our substantial range in IBA dose did not eliminate this undesirable behavior.

Why would exogenous IBA with such an extreme range in concentration garner minimal AR response from these two Zamia species? We consider several issues related to auxin dosage. First, Zamia stem cuttings may require minimal auxin concentration for AR formation. Second, Zamia stems may produce a copious amount of endogenous indole-3-acetic acid (IAA) that is greater than the auxin dose needed for maximum AR formation, and additional exogenous IBA is unnecessary. Plants employ several mechanisms for maintaining auxin homeostasis, including inactivation of excess auxin by oxidation or conjugation (Woodward and Bartel, 2005). Recent research on conifers suggest oxidation is minimally used but conjugation is employed to inactivate excessive levels of IAA when auxin is applied exogenously (Brunoni et al., 2020). Although cycads and conifers are both gymnosperms, the branching process that initiated the cycad lineage began millions of years before conifers (Norstog and Nicholls, 1997). Therefore, cycads as a group may not behave in a similar manner to exogenously applied auxin. However, our results indirectly suggest that cycads may inactivate exogenously applied auxin, as our high dose of $30 \mathrm{mg} \cdot \mathrm{g}^{-1}$ caused no negative responses. Further research is required to determine the extent of these behaviors in cycad plants. This could begin with quantifying baseline IAA levels in healthy stem cuttings of a range of cycad species.

The unexpected results may also be explained by factors that indirectly influence plant responses to auxin. First, the concentrations of various nonstructural carbohydrates interact with auxin to influence AR formation and growth (Calamar and de Klerk, 2002; Jackson, 1986; Pawlicki and Welander, 1995; Qi et al., 2020; Veierskov, 1988). Healthy cycad stems are composed of living parenchymatous tissue containing copious amounts of nonstructural carbohydrates (Marler, 2018a,c; Norstog and Nicholls, 1997). Reduced success of AR formation in C. micronesica has been reported for stem cuttings obtained from unhealthy trees (Marler, 2018c), and the reduced carbohydrate concentrations in the unhealthy cuttings may have been causal. Second, the concentrations of stem nutrients may also interact with auxin and carbohydrates to influence AR formation and growth (Dick and Dewar, 1992; Druege et al., 2004; Jackson, 1986). The manoxylic stems of cycads contain an abundance of plant nutrients (Marler, 2018b), and this relative abundance of nutrients may maximize the AR initiation of cycad stem cuttings in the presence of auxin. Third, auxin exerts its influence on stem AR formation by interacting with other hormones (AgullóAntón et al., 2014). To our knowledge, the cycad literature does not contain any mention 


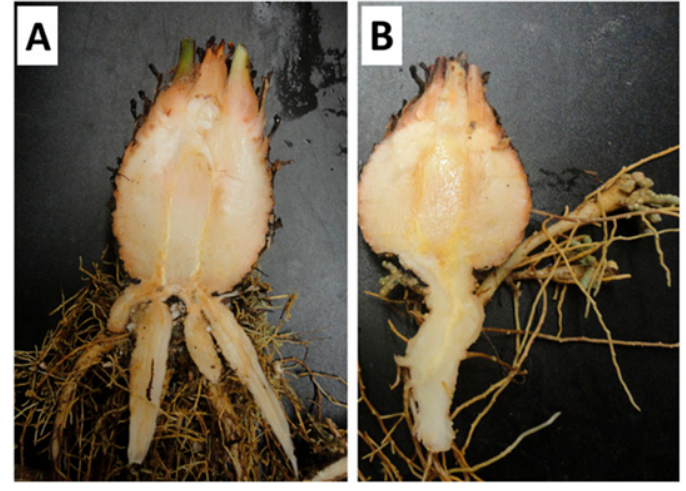

Fig. 3. Sections of rooted (A) Zamia furfuracea and (B) Zamia integrifolia stem cuttings revealing vascular tissues within adventitious roots. The adventitious roots were connected to pre-existing vascular tissues within the stem cuttings.

of endogenous hormone concentrations in cycad stem cuttings used for asexual propagation. The influences of relevant hormones, carbohydrates, and minerals on the auxin dose response during AR formation in stem cuttings are not fully understood. Further research is required to determine if cycad stems maximize the benefits of non-auxin hormones and all nonstructural resources such that exogenous IBA is not required for $\mathrm{AR}$ initiation and growth.

The $Z$. integrifolia plants exhibited more coralloid root clusters than the $Z$. furfuracea cuttings ( 10 per plant vs. 6 per plant). Cycad coralloid roots contain nitrogen-fixing endosymbionts (Norstog and Nicholls, 1997). The reasons for this species difference are unknown, but the observation indicates the relative construction and dependence on coralloid root nitrogen may be greater for $Z$. integrifolia. This suggests that $Z$. integrifolia plants may require more fixed nitrogen to grow in their native habitats. Further research on species specific differences on coralloid root dependence could shed more light on the role of cycad root endosymbionts on their growth.

Our results may benefit rural cycad nursery operations in countries with threatened cycad species. For example, Vovides et al. (2006) detailed efforts by rural plant nurseries in Mexico to propagate cycads from wild source material, thus reducing the pressure on illegal collecting of cycads in their natural habitats. Farmers were encouraged to propagate cycads as a means of additional income and to protect the habitats as their seed source. The authors also reported reintroduction of nursery-produced seeds into their respective habitats. These sorts of community programs would benefit from expanded horticultural research to support decision making. In many countries, commercial IBA products may be difficult to obtain. Our results are of great importance to cycad horticulturists in these geographic locations. If exogenous IBA is not needed to improve the asexual propagation of cycad by stem cuttings, then no effort is required to find a commercial source of IBA.

In conclusion, cycads have existed on Earth for over 200 million years, living alongside the dinosaurs and surviving their extinction. Their slow growth habit and often limited natural distributions have made them especially vulnerable to anthropogenic influences such as deforestation and poaching (Norstog and Nicholls, 1997). The time to produce new cycad plants asexually is often constrained by the time the "pups" spend in the nursery. We have shown that a range of exogenous IBA dosage did not increase success or shorten the time required for cuttings of two Zamia species to produce adventitious roots. Additional cycad genera and species should be included in future studies, as the results from these studies may not be comparable to the other 9 genera and $350+$ species.

\section{Literature Cited}

Agulló-Antón, M.Á., A. Ferrández-Ayela, N. Fernández-García, C. Nicolás, A. Albacete, F. Pérez-lfocea, J. Sánchez-Bravo, J.M. PérezPérez, and M. Acosta. 2014. Early steps of adventitious rooting: Morphology, hormonal profiling and carbohydrate turnover in carnation stem cuttings. Physiol. Plant. 150:446462 .

Azad, Md. S. and Md. A. Matin. 2015. Effect of Indole-3-Butyric Acid on clonal propagation of Swietenia macrophylla through branch cutting. J. Bot. 15(249308).

Brondani, G.E., I. Wendling, A.E. Brondani, M.A Araujo, A.L.L. Silva, and A.N. Goncalves. 2012. Dynamics of adventitious rooting in mini-cuttings of Eucalyptus benthamii x Eucalyptus dunnii. Acta Scientiarum 34(2):169178.

Brummitt, N.A., S.P. Bachman, J. Griffiths-Lee, M. Lutz, J.F. Moat, A. Farjon, J.S. Donaldson, C.H. Ilton-Taylor, T.R. Meagher, S. Albuquerque, E. Aletrari, A.K. Andrews, G. Atchison, E. Baloch, B. Barlozzini, A. Brunazzi, J. Carretero, M. Celesti, H. Chadburn, E. Cianfoni, C. Cockel, V. Coldwell, B. Concetti, S. Contu, V. Crook, P. Dyson, L. Gardiner, N. Chanim, H. Greene, A. Groom, R. Harker, D. Hopkins, S. Khela, P. Lakeman-Fraser, H. Lindon, H. Lockwood, C. Loftus, D. Lombrici, L. Lopez-Poveda, L. Lyon, K. Malcolm-Tompkins, L. Moreno, L. Murray, K. Nazar, E. Power, M.Q. Tuijelaars, R. Salter, R. Segrott, H. Thacker, L.J. Thomas, S. Tingvoll, G. Watkinson, K. Wojtaszekova, and E.M.N. Lughadha. 2015. Green plants in the red: A baseline global assessment for the IUCN sampled red list index for plants. PLoS One 10(8):E0135152.

Brunoni, F., S. Collani, R. Casanova-Sáez, J. Šimura, M. Karady, M. Schmid, K. Ljung, and C. Bellini. 2020. Conifers exhibit a characteristic inactivation of auxin to maintain tissue homeostasis. New Phytol. 226:17531765.

Calamar, A. and G.-J. de Klerk. 2002. Effect of sucrose on adventitious root regeneration in apple. Plant Cell Tissue Organ Cult. 70:207212.

Calonje, M., D.W. Stevenson, and L. Stanberg. 2020. The world list of cycads, online edition, 2013-2020. 6 March 2020. <http://www.cycadlist. org $>$.

Cooper, W.C. 1935. Hormones in relation to root formation on stem cuttings. Plant Physiol. 10:789-794.

Dehgan, B. 1983. Propagation and growth of cycads: A conservation strategy. Proc. Annu. Meet. Fla. State Hort. Soc. 96:137-139.

Dehgan, B. 1999. Propagation and culture of cycads: A practical approach. Acta Hort. 486:123-132.

Dehgan, B., F.C. Almira, A.E. Dudeck, and B. Schutzman. 1994. Effects of varying shade and fertilizer on the growth of Zamia floridana A.DC. Bot. Rev. 70(1):79-85.

Dehgan, B. and C.R. Johnson. 1987. Root branching in Zamia floridana: Effect of growth regulators and anatomical features. J. Amer. Soc. Hort. Sci. 112:1041-1044.

Dick, J.M. and R.C. Dewar. 1992. A mechanistic model of carbohydrate dynamics during adventitious root development in leafy cuttings. Ann. Bot. 70:371-377.

Druege, U., S. Zerche, and R. Kadner. 2004 Nitrogen- and storage-affected carbohydrate partitioning in high-light-adapted Pelargonium cuttings in relation to survival and adventitious root formation under low light. Ann. Bot. 94:831-842.

Fragniere, Y., S. Betrisey, L. Cardinaux, M. Stoffel, and G. Kozlowski. 2015. Fighting their last stand? A global analysis of the distribution and conservation status of gymnosperms. J. Biogeogr. 42(5):809-820.

Hartmann, H.T., D.E. Kester, and F.T. Davies, Jr. 1990. Plant propagation: Principles and practices. Prentice Hall, Englewood Cliffs, NJ.

Jackson, M.B. (ed.). 1986. New root formation in plants and cuttings. Martinus Nijhoff, Leiden, Netherlands.

Jones, D. 1993. Cycads of the World. The Smithsonian Institution Press, Washington, D.C.

Kay, J., A.A. Strader, V. Murphy, L. Nghiem-Phu, M. Calonje, and M.P. Griffith. 2011. Palma Corcho: A case study in botanic garden conservation horticulture and economics. HortTechnology 21:474-481.

Ky-Dembele, C., M. Tigabu, J. Bayala, P. Savadogo, I.J. Boussim, and P.C. Oden. 2011. Clonal propagation of Khaya senegalensis: The effects of stem length, leaf area, auxins, smoke solution, and stockplant age. Intl. J. For. Res. 18:1-10.

Mamay, S.H. 1969. Cycads: Fossil evidence of late paleozoic origin. Science 164:295-296.

Marler, T.E. 2017. Horticultural research crucial for plant conservation and ecosystem restoration. HortScience 52:1648-1649.

Marler, T.E. 2018a. Axial and radial spatial patterns of non-structural carbohydrates in Cycas micronesica stems. Plants 7:49.

Marler, T.E. 2018b. Elemental profiles in Cycas micronesica stems. Plants 7:94. 
Marler, T.E. 2018c. Stem carbohydrates and adventitious root formation of Cycas micronesica following Aulacaspis yasumatsui infestation. HortScience 53:1125-1128.

Marler, T.E., A. Lindström, and J.B. Fisher. 2010. Stem tissue dimensions correlate with ease of horticultural management for six Cycas species. HortScience 45:1293-1296.

Marler, T.E. and G. Cruz. 2017a. Adventitious rooting of mature Cycas micronesica K.D. Hill (Cycadales: Cycadaceae) tree stems reveals moderate success for salvage of an endangered cycad. J. Threat. Taxa 9(8):10565-10570.

Marler, T.E. and G.N. Cruz. 2017b. Best protocols for cycad propagation require more research. $\mathrm{J}$. Threat. Taxa 9(9):10738-10740.

Marler, T.E., B.E. Deloso, and G.N. Cruz. 2020. Prophylactic treatments of Cycas stem wounds influence vegetative propagation. Trop. Conserv. Sci. 13:1-6.
Norstog, K.J. and T.J. Nicholls. 1997. The biology of the cycads. Cornell Univ. Press, Ithaca, NY.

Pawlicki, N. and M. Welander. 1995. Influence of carbohydrate source, auxin concentration and time of exposure in adventitious rooting of the apple rootstock Jork 9. Plant Sci. 106:167-176.

Purohit, V.K., P.C. Phondani, L.S. Rawat, R.K. Maikhuri, D. Dhyani, and A.R. Nautiyal. 2009. Propagation through rooting of stem cuttings of Ginkgo biloba, a living fossil under threat. J. Amer. Sci. 5(5):139-144.

Qi, X., Q. Li, J. Shen, C. Qian, X. Xu, Q. Xu, and X. Chen. 2020. Sugar enhances waterlogginginduced adventitious root formation in cucumber by promoting auxin transport and signalling. Plant Cell Environ. 43:1545-1557.

Shirzad, M., S. Sedaghathoor, and S. Hashemabadi. 2012. Effects of media and different concentrations of IBA on rooting of 'Ficus benjamina L. ' cutting. J. Ornamental Hort. Plants 2:61-64.
Stopes, M.C. 1910. Adventitious budding and branching in Cycas. New Phytol. 9:235-241.

Tang, W. 1985. Handbook of cycad cultivation and landscaping. Published by the author, Miami, FL.

Veierskov, B. 1988. Relations between carbohydrates and adventitious root formation; p. 7078. In: T.D. Davis, B.E. Haissig, and N. Sankhla (eds.). Adventitious root formation in cuttings. Dioscorides Press, Portland, OR.

Vovides, A.P., M.A. Pérez-Farrera, and C. Iglesias. 2006. Sixteen years of cycad propagation in Mexico: An alternative conservation strategy aimed at sustainable management. The Nature of Success: Success for Nat. 2006. conference paper, 1-6.

Whitelock, L.M. 2002. The cycads. Timber Press, Portland, OR.

Woodward, A.W. and B. Bartel. 2005. Auxin: Regulation, action, and interaction. Ann. Bot. 95:707-735. 